\title{
Low Impact Felling Distance and Allowable Number of Felled Trees in TPTI System
}

\author{
Ahmad Budiaman*, Adita Agung Pradata \\ Department of Forest Management, Faculty of Forestry, Bogor Agricultural University, Academic Ring Road, Campus IPB \\ Dramaga, PO Box 168, Bogor 16680, Indonesia
}

Received July 22, 2013/Accepted December 5, 2013

\begin{abstract}
Indonesian Selective Cutting and Planting System (TPTI) is a silvicultural system of production natural forests management conducted in Indonesia. TPTI implementation has resulted in damage to the residual stands and threatened the existence of production natural forests in Indonesia. This study assessed the damage level of the residual stands of commercial species due to low cutting intensity $\left(0.77\right.$ trees ha $\left.{ }^{-1}\right)$, calculated low damages cutting distance, and determined the number of trees ha $a^{-1}$ which could be harvested sustainably. Dynamic sample plots with a circular shape with a radius of 2 times the height of felled trees were used in this study, and the number of sample plots was 29 plots with an average area of $1.3 \mathrm{ha}$. In the sample plots, the tree species, total height, diameter at breast height (dbh), and number of commercial trees $\geq 10 \mathrm{~cm}$ dbh were measured before and after cutting. The results showed that the damage level of residual stands caused by the low cutting intensity was $2.1 \%$, where the damages included broken stems, splitted stems, and injured stems, leaning trees, fallen trees, broken crowns and broken buttresses. The low cutting intensity had damaged 7 commercial tree species with the diameter $\geq 10 \mathrm{~cm}$. The study recommends sustainable cutting on TPTI with a distance of $>1.5$ times the height of felled trees and the number of trees $h a^{-1}$ that may be sustainably felled is no more than 5 trees $h a^{-1}$.
\end{abstract}

Keywords: TPTI, commercial residual stand, cutting distance, sustainability

\begin{abstract}
Abstrak
Sistem Tebang Pilih Tanam Indonesia (TPTI) tidak mengatur batasan jumlah pohon ha ${ }^{-1}$ yang boleh ditebang, sehingga memungkinkan untuk menebang hutan dengan intensitas penebangan tinggi. Penerapan TPTI telah mengakibatkan kerusakan tegakan tinggal dan mengancam eksistensi hutan alam produksi di Indonesia. Penelitian ini menilai tingkat kerusakan tegakan tinggal jenis komersial akibat penebangan intensitas rendah $(0,77$ pohon $\left.\mathrm{ha}^{-1}\right)$, menghitung jarak tebang lestari dan menentukan jumlah pohon ha ${ }^{-1}$ yang boleh ditebang secara lestari. Plot contoh dinamis berbentuk lingkaran dengan jari-jari sebesar 2 kali tinggi pohon yang ditebang digunakan dalam penelitian ini. Jumlah plot contoh sebanyak 29 dengan luas rata-rata sebesar 1,3 ha. Pada plot contoh dilakukan pengukuran tinggi, diameter dan jumlah pohon komersial berdiameter $\geq 10 \mathrm{~cm}$ sebelum dan sesudah penebangan. Hasil penelitian menunjukkan bahwa tingkat kerusakan tegakan tinggal akibat penebangan dengan intensitas rendah sebesar 2,1\%, dengan tipe kerusakan berupa patah batang, pecah batang, luka batang, pohon miring, pohon roboh, rusak tajuk dan rusak banir. Penebangan pohon dengan intensitas rendah mengakibatkan 7 pohon jenis komersial berdiameter $\geq 10 \mathrm{~cm}$ mengalami kerusakan. Penelitian ini merekomendasikan jarak tebang pohon lestari pada TPTI $>45 \mathrm{~m}$ atau $>1,5$ kali tinggi pohon yang ditebang dan jumlah pohon ha $a^{-1}$ yang boleh ditebang secara lestari tidak lebih dari 5 pohon $\mathrm{ha}^{-1}$.
\end{abstract}

Kata kunci: TPTI, tegakan tinggal, jaraktebang, kelestarian

*Correspondenceauthor,email:abudiam@yahoo.co.id,tel:+62-251-8621244,fax.:+62-251-8621244

\section{Introduction}

Concession of production natural forests in Indonesia was begun in 1970 with the Indonesian Selective Cutting System (TPI), which was based on a diameter limit of 50-60 $\mathrm{cm}$ with the absence of silvicultural treatment and depended on the type of forests (Soerianegara 1971). The TPI system was revised into Indonesian Selective Cutting and Planting System (TPTI) in 1989, and its contents were not substantially different from those of the TPI system in 1970. TPTI system sets limitations of diameter of trees that can be cut, cutting cycle, and number of core trees and limit of core tree diameter. Meanwhile, the principle of yield regulation of production natural forests in Indonesia using TPTI system is essentially based on the number of trees (Indrawan 2003). Although TPTI has been revised and the regulation of the yields is still based on the number of trees, there has been no 
change in the regulation of the allowable number of trees to be felled ha ${ }^{-1}$. The regulation based on the diameter of the trees felled will give an opportunity to cut trees with high intensity at a given unit area $\left(\mathrm{ha}^{-1}\right)$. Tree cutting with high intensity has caused great damages, including the commercial residual stand damages.

The use of TPTI system on natural forest management has still produced a risk of damage to the environment, such as causing the degradation of tropical forests of Indonesia (Hamilton 1997; Verissimo et al. 1992) and damaging residual stands (Bertault and Sist 1997; Sist et al. 1998; van Kuijk et al. 2009; Putz et al. 2011). In addition, changes in the residual stand conditions due to selective cutting system can cause changes in the composition of forest stands (Uutera et al. 2000; Indrawan 2003; Muhdin et al. 2008: van Kuijk et al. 2009; Muhdin et al. 2011); changes in tree density (Cannon et al. 1994), and changes in the frequency distribution of tree size (van Kuijk 2009).

The damage level of residual stands caused by tree cuttings with the selective cutting system was influenced by cutting intensity, forest harvesting techniques, and forest management types. Bertault and Sist (1997) reported that the conventional logging by $87 \mathrm{~m}^{3} \mathrm{ha}^{-1}$ had damaged trees with a diameter $>10 \mathrm{~cm}$ as much as $40 \%$, whereas the reduce impact logging (RIL) techniques had caused damages by $30.5 \%$. Sist et al. (1998) reported that the cutting intensity of 8 trees $^{-1}{ }^{-1}$ or less using the RIL techniques resulted in tree damages by $25 \%$, while the conventional logging technique had caused damages by $48 \%$. Jackson et al. (2002) reported that the intensity of tree cuttings of 4.3 trees $\mathrm{ha}^{-1}$ by using RIL technique in Bolivia resulted in damage to the residual stands by $45.8 \%$. If one tree was extracted, it would result in the damage of 44 other trees, including 6 commercial tree species. In addition to the intensity of cutting and harvesting techniques, and types of forest management can affect the level of damages to the residual stands, as reported by Alexander et al. (2006) stating that harvesting permission intended for local communities, known as Izin Pemungutan dan Pemanfaatan Kayu (IPPK), had resulted in residual stand damage by 2 times larger than forest concesion holder (known as Hak Pengusahaan Hutan) for trees $<50 \mathrm{~cm}$ $\mathrm{dbh}$. Residual stand damages can be reduced if the number of trees harvested in an area is limited (Sist et al. 1997). Another disadvantage of this TPTI system is that it is not compatible with the principles of forest sustainability as it is only based on diameter limit, so that it requires a better regulation for the selection of cut trees (Sist et al. 1997). In addition to limiting the number of trees felled $\mathrm{ha}^{-1}$, TPTI should regulate the cutting distance so that forest degradation can be minimized. Sist et al. (2003) suggested that the minimum distance between trees felled should be more than $40 \mathrm{~m}$. There have been only a few studies on the minimum felling distance on selective cutting system performed in the production natural forest management in Indonesia.

The addition of restrictions on the number of trees that can be cut ha ${ }^{-1}$ and minimum felling distance in TPTI system is a crucial requirement, considering the fact that tree distribution in natural forests is uneven and irregular, with a high destruction of Indonesia's natural forests due to TPTI, and TPTI system has still been used in the concession of production natural forests. Therefore, studies on reducing commercial residual stand damages on production natural forests in Indonesia are a necessity. This study aimed to assess the damage on residual stands of commercial species with a diameter of $\geq 10 \mathrm{~cm}$ due to cutting intensity, to measure low impact felling distance, and to count the number of trees that may be felled $\mathrm{ha}^{-1}$ in TPTI system to minimize damages to residual stands of commercial species.

\section{Methods}

Description of the study site The study was conducted in one of the forest concession holder (IUPHHK-HA) in Papua Province. The IUPHHK-HA forest area is located in the group of Forest Rivers of Mamberamo and Gesa. The study site was geographically located at $137^{\circ} 46-140^{\circ} 19$ East Longitude and $01^{\circ} 28-03^{\circ} 50$ South Latitude. Based on the Schmidt-Ferguson's climate classification, the IUPHHKHA forest area belongs to type A climate where the average temperature varies from $22-27{ }^{\circ} \mathrm{C}$ and average annual rainfall varies at $2,500-5,000 \mathrm{~mm}$. The total area of IUPHHK-HA is 677,310 ha, which consists of a permanent production forest of $17.3 \%$, limited production forest of $75.8 \%$ and convertible production forest of $6.9 \%$. The topography of the concession area is mostly reasonably steep terrain. Soil types of the study area include alluvial, latosols, podzolic, litosol, and regosol. The harvesting technique used is a conventional logging.

Sample plots The study was conducted in 2012 in a compartment of a-100 ha area on annual working plan 2012. As many as 29 trees were purposively selected to be cut in this compartment. This number of trees was determined based on the diameter distribution of tree felled with a sampling error of $10 \%$. The circular plot was used with sample trees chosen as the central point of the plot; thus, the number of sample plots was 29 plots. The plot radius was set at two times the total height of the trees felled so that the size of each plot was different, and it was also called a dynamic plot. The plot size ranged from 0.8 to 1.9 ha and averaged 1.3 ha. The shape and size of the sample plots adopted the dangerous area limitation on tree cutting activity, and this dangerous area was the same as that of the circumference with a radius of two times the total height of the tree felled.

Data collection Forest inventory on stands before cutting was conducted on all types of commercial trees with a diameter of $\geq 10 \mathrm{~cm}$ at the sample plots. The measured variables included tree species, height, $\mathrm{dbh}$, and number of trees. The trees in the central plots were cut by the company cutting crew using chain saws. After the cutting had been done at the central plots, a forest inventory on residual stands of all types of commercial trees with a diameter $\geq 10 \mathrm{~cm}$ which were damaged by cutting was conducted. This treatment was called low cutting intensity (one tree plot $^{-1}$ or 0.77 trees $^{-1} \mathrm{a}^{-1}$ ). The following observations were carried out again on the same plot after cutting activities have been completed by the company. The activities conducted are forest inventory on stands of post-cutting of all commercial 
trees with the diameter of $\geq 10 \mathrm{~cm}$ damaged by the cutting practices conducted by the company. This treatment was called high cutting intensity.

The damages of residual stands were grouped into 7 classes, namely (1) broken crowns, (2) stem injury, (3) splitted stems, (4) broken stems, (5) leaning tree, (6) fallen trees, and (7) buttress damage. The tree damage level was expressed as the ratio between the number of trees damaged by cutting and the number of trees before cutting (\%). Other parameters measured in sample plots included the area length affected by a low cutting intensity. The impact length due to the low cutting intensity in each plot was measured. Measurement of the impact length of cutting was measured from the stumps of felled trees to the outermost point of the area affected by this cutting.

Forest stands before cutting The average height of the central trees was $32 \mathrm{~m}$, so that the average radius of the sample plots was $64 \mathrm{~m}$. The average sample plot area was 1.3 ha and average number of commercial trees with a diameter of $\geq 10 \mathrm{~cm}$ was 347 trees plot $^{-1}$. Thus, the average density of commercial trees with a diameter of $\geq 10 \mathrm{~cm}$ at the sample plots was 284 trees $^{-1} a^{-1}$. The results showed that the tree density $\mathrm{ha}^{-1}$ in the study area was smaller than the results of the study that had been conducted in Papua Province. Kuswandi (2003) reported that the density of stands at other locations in Papua was 321 trees ha $^{-1}$. The commercial tree species with a diameter of $\geq 10 \mathrm{~cm}$ in the sample plots were dominated by non-Dipterocarp group $(77.1 \%)$, whereas the rest $(22.9 \%)$ came from Dipterocarp group. This study produced different data from the study results conducted in the western region of Indonesia. Brearly et al. (2004) reported that tree species that dominated tropical primary forests in Central Kalimantan was Dipterocarp group.

Based on the tree growth stage, it can be seen that the total number of the poles $(48.5 \%)$ did not vary much with the total of trees in each plot $(51.5 \%)$. Based on the distribution of tree diameter, it can be said that the larger the diameter of a tree is, the fewer the total number of trees is. The total number of commercial trees with a diameter of $10-19 \mathrm{~cm}$ was $48.5 \%$ and trees with a diameter above $50 \mathrm{~cm}$ were only $2.8 \%$. This trend occurs in all commercial tree species, i.e. Dipterocarp and non-Dipterocarp groups. The total number of trees of commercial species with a diameter $\geq 10 \mathrm{~cm}$ before cutting is presented at Table 1 .
Residual stand damages due to low cutting intensity The total number of commercial trees with a diameter of $\geq 10 \mathrm{~cm}$ damaged by low cutting intensity was 207 trees $(2.1 \%$ of the number of trees before cutting), which consisted of 113 poles and 94 trees. Cutting of a tree of commercial species plot ${ }^{-1}$ can lead to damages of approximately 7 trees ha $^{-1}$ of commercial species with a diameter of $\geq 10 \mathrm{~cm}$, which consisted of 4 poles $(54.6 \%)$ and 3 trees $(45.4 \%)$. The total number of trees damaged due to cutting with an intensity of $0.77 \mathrm{ha}^{-1}$ in Papua, Indonesia,; was smaller than that of the study results in Bolivia, Brazil and Gabon. Jackson et al. (2002) reported that the cutting in Bolivia resulted in 14.6 of other trees damaged; moreover, Johns et al. (1996) reported that the cutting in Brazil resulted in 20.5 of other trees damaged. Meanwhile, Medjibe et al. (2011) reported that the cutting with an intensity of 0.82 trees $\mathrm{ha}^{-1}$ in Gabon resulted in the damage of 11 commercial trees with a diameter $\geq 10$. Residual stand damages due to low cutting intensity in Papua was smaller than the allowable damage level in some countries which apply the threshold level of residual stand damage due to forest harvesting activities. Han and Kellogg (2000) stated that the authorities could stop forest cutting operations whenever residual stand damage level occurred was above the allowable level. In United State of America, a penalty can be given to logging companies if damage of residual stands due to harvesting activities exceeds $5 \%$. The total number of trees damaged by low cutting intensity in Papua is presented at Table 2 .

Based on the species group, Dipterocarp group had lower damages when compared with non-Dipterocarp group. The percentages of damages of the residual stands of Dipterocarp group and non-Dipterocarp group reached $21.3 \%$ and $78.7 \%$ respectively. This large difference occurred because the density of Dipterocarp group (62 trees ha ${ }^{-1}$ ) was lower than that of the non-Dipterocarp group (209 trees $\mathrm{ha}^{-1}$ ). The percentages of residual stand damages caused by low cutting intensity based on diameter class and species groups are presented at Table 3 .

Table 3 showed that the greatest level of residual stand damage was in the diameter class of 10-19 cm (54.6\%), while the smallest level of damage occurred in the diameter class above $50 \mathrm{~cm}(1.9 \%)$. The results showed that the larger tree diameter, the smaller level of damage. The trend occurred in Dipterocarp and non-Dipterocarp groups. These

Table 1 Number of commercial trees with a diameter of $\geq 10 \mathrm{~cm}$ based on diameter classes and species groups before tree cuttings $(\mathrm{N}=29$ plots $)$

\begin{tabular}{lcccccccc}
\hline \multirow{2}{*}{ Species gorups } & \multicolumn{4}{c}{ Diameter classes (cm) } & \multicolumn{3}{c}{ Total } \\
\cline { 2 - 8 } & & $10-19$ & $20-29$ & $30-39$ & $40-49$ & $\geq 50$ & $\mathrm{~N}$ & $\%$ \\
\hline Dipterocarp & 946 & 695 & 366 & 197 & 82 & 2,286 & 22.9 \\
Non-Dipterocarp & & 3,899 & 2,186 & 1,057 & 369 & 197 & 7,708 & 77.1 \\
All species & $\mathrm{n}$ & 4,845 & 2,881 & 1,423 & 566 & 279 & 9,994 & - \\
& $\%$ & 48.5 & 28.8 & 14.2 & 5.7 & 2.8 & - & - \\
\hline
\end{tabular}


Table 2 Number of poles and commercial tree species damaged due to low cutting intensity $\left(0.77\right.$ trees ha $\left.{ }^{-1}\right)(\mathrm{N}=29$ plots $)$

\begin{tabular}{lcccc}
\hline \multirow{2}{*}{ Stage of tree growth } & \multicolumn{3}{c}{ Total of trees } \\
\cline { 2 - 5 } & Before cutting & After cutting & \multicolumn{2}{c}{ Damaged trees } \\
\cline { 2 - 5 } & $(\mathrm{n})$ & $(\mathrm{n})$ & $(\mathrm{n})$ & $(\%)$ \\
\hline Poles & 4,845 & 4,732 & 113 & 54.6 \\
Trees & 5,149 & 5,055 & 94 & 45.4 \\
& 9,994 & 9,787 & 207 & 100 \\
\hline
\end{tabular}

Table 3 The number of commercial trees with a diameter of $\geq 10 \mathrm{~cm}$ before and after cutting, the number of damaged trees due to low cutting intensity $(\mathrm{N}=29$ plots $)$

\begin{tabular}{|c|c|c|c|c|c|c|}
\hline & \multicolumn{5}{|c|}{ Diameter classes $(\mathrm{cm})$} & \multirow[t]{2}{*}{ Total } \\
\hline & $10-19$ & $20-29$ & $30-39$ & $40-49$ & $\geq 50$ & \\
\hline \multicolumn{7}{|l|}{ 1. Before cutting } \\
\hline Dipterocarp (tree ha ${ }^{-1}$ ) & 26 & 19 & 10 & 5 & 2 & 62 \\
\hline Non-Dipterocarp (tree ha ${ }^{-1}$ ) & 106 & 60 & 29 & 10 & 5 & 210 \\
\hline All species $\left(\right.$ tree ha $\left.{ }^{-1}\right)$ & 132 & 79 & 39 & 15 & 7 & 272 \\
\hline Basal area all species $\left(\mathrm{m}^{2} \mathrm{ha}^{-1}\right)$ & 1.6 & 2.8 & 2.7 & 2.1 & 2.2 & 11.3 \\
\hline \multicolumn{7}{|l|}{ 2. After cutting } \\
\hline Dipterocarp $\left(\right.$ tree $\left.\mathrm{ha}^{-1}\right)$ & 25 & 19 & 10 & 5 & 2 & 61 \\
\hline Non-Dipterocarp (tree ha ${ }^{-1}$ ) & 104 & 58 & 28 & 10 & 5 & 206 \\
\hline All species (tree ha-1) & 129 & 77 & 38 & 15 & 7 & 267 \\
\hline Basal area all species $\left(\mathrm{m}^{2} \mathrm{ha}^{-1}\right)$ & 1.5 & 2.7 & 2.6 & 2.1 & 2.2 & 11.1 \\
\hline \multicolumn{7}{|l|}{ 3. Damage class $(\%)$} \\
\hline Broken stems & 41.6 & 27.9 & 22.5 & 9.1 & 33.3 & \\
\hline Fallen trees & 20.4 & 30.9 & 20.0 & 27.3 & 0.0 & \\
\hline Broken crowns & 15.0 & 22.1 & 32.5 & 18.2 & 50.0 & \\
\hline Leaning trees & 9.7 & 1.5 & 2.5 & 9.1 & 0 & \\
\hline Stem injury & 9.7 & 8.8 & 7.5 & 27.3 & 0.0 & \\
\hline Splitted stems & 3.5 & 8.8 & 15.0 & 9.1 & 0.0 & \\
\hline Broken buttresses & 0 & 0 & 0 & 0 & 16.7 & \\
\hline
\end{tabular}

data also indicated that the total number of trees at the higher diameter class in natural forests was less than that of the smaller diameter class. This is consistent with the Liocourtcurve using geometric regression that the total number of trees in tropical natural forests applying the selective cutting system became less from one class to the next larger class (Osmaton 1968).

Cutting of one tree plot $^{-1}$ resulted in all types of tree damage, such as broken stems, splitted stems, leaning trees, fallen trees, broken crowns, stem injury, and broken buttresses. Type of tree damage at the stands with the greatest level was broken stems $(41.59 \%)$, and the rest were fallen trees $(20.35 \%)$, broken crowns $(15.04 \%)$, stem injury $(9.73 \%)$, leaning trees $(9.73 \%)$ and splitted stems $(3.54 \%)$. Meanwhile, there was no damage in buttresses at the poles. At the tree stage, all types of tree damage due to cutting occurred in all sample plots. The largest damage type due to cutting was crown damage $(26.60 \%)$ and the smallest damage was broken buttresses $(1.06 \%)$. Study in Gabon showed that the types of damage caused by cutting of 0.82 trees ha $^{-1}$ resulted in only 3 types of damages, including damaged stems, broken crowns and broken buttresses (Medjibe et al. 2011).
Residual stand damages due to high cutting intensity Table 4 presents the data on the damage levels of residual stands of commercial species with low and high cutting intensity. The average high cutting intensity was as many as 10 trees $\mathrm{ha}^{-1}$. The total number of commercial trees with a diameter of $\geq 10 \mathrm{~cm}$ damaged by high cutting intensity reached 2,408 (24.1\% of the total number of trees before cutting), which comprised 1,285 of poles and 1,123 of trees. High cutting intensity resulted in damages of an average of 64 trees ha $^{-1}$ of commercial species with a diameter of $\geq 10$ $\mathrm{cm}$. The damaged trees consisted of 34 poles $(53.1 \%)$ and 30 trees $(46.9 \%)$. Cutting with an intensity cutting of 10 trees per ha ${ }^{-1}$ had resulted in damages of the residual stands of commercial species 11 times larger than the damages due to the cutting of 0.77 per $\mathrm{ha}^{-1}$. The damage levels of residual stands of commercial species caused by high cutting intensity at the poles and trees stages were $26.52 \%$ and $21 \%$ respectively. The damage level of residual stands was influenced by the cutting intensity and cutting techniques. The higher intensity of cutting is, the higher residual stand damage is. Sist et al. (1998) reported that the cutting 
intensity of 8 trees ha ${ }^{-1}$ or less with the RIL technique would cause damaged trees by $25 \%$, while the conventional technique caused damaged trees by $48 \%$. In addition, Putz et al. (2000) suggested that the cutting intensity in tropical rain forests in Asia and Pacific regions was much higher than that in other tropical regions.

The percentage of residual stand damage for Dipterocarp group was $21.35 \%$, consisting $10.94 \%$ damage on the $10-19$ cm diameter class, $4.33 \%$ damage on the 20-29 $\mathrm{cm}$ diameter class, $3.59 \%$ damage on the $30-39 \mathrm{~cm}$ diameter class, $1.57 \%$ damage on the $40-49 \mathrm{~cm}$ diameter class, and $0.92 \%$ damage on a diameter class of $\geq 50 \mathrm{~cm}$. The residual stand damages of commercial species occurred on the diameter class of 10-19 $\mathrm{cm}$, as amount as $26.43 \%$ of the total damages. This occurred because trees with a diameter class of $10-19 \mathrm{~cm}$ had a higher density than trees in the other diameter classes. The residual stand damage that occurred in Dipterocarp group was $24.52 \%$, in which the percentages of damages based on the diameter classes of $10-19 \mathrm{~cm}, 20-29 \mathrm{~cm}, 30-39 \mathrm{~cm}, 40-49$ $\mathrm{cm}$, and $\geq 50 \mathrm{~cm}$ were $13.43 \%, 7.12 \%, 3.36 \%, 0.43 \%$, and $0.18 \%$ respectively. Like Dipterocarp group, the largest residual stand damage in the non-Dipterocarp group occurred on the 10-19 cm diameter class (26.55\%). This can be explained that the trees of non-Dipterocarp group with a diameter of 10-19 cm class had a higher density than the trees from the other diameter classes. The damage levels of residual stands of the Dipterocarp group and nonDipterocarp group due to high cutting intensity are presented at Table 5.

Low impact felling distance Plots used in this study were dynamic plots in a circular shape with a radius 2 times the total height of the central trees felled. The shape and size of the plots were more facilitated the measurement of the outer length affected by cutting than the other plot shapes of rectangle or square, because the entire areas affected by the cutting was located inside the plots, so that the areas affected could be determined more accurately. The average height of the trees felled was $32 \mathrm{~m}$, and the average length of the outermost point affected by one-tree cutting was $45 \mathrm{~m}$ or approximately 1.5 times the average height of the trees felled. Based on the impact length of tree cutting, the distance between the trees felled which reduced the damages of residual stands of commercial species was $>45 \mathrm{~m}$. The results showed that low cutting intensity produced the damage level of residual stands of commercial species by $2.1 \%$ only, while the high cutting intensity produced the damage level of $26.52 \%$. The reasonably safe distance between trees felled in Papua was not different from the result of previous study in Borneo. Sist et al. (2003) suggested that the minimum distance between trees felled was $40 \mathrm{~m}$.

Based on the low impact felling distance, the number of trees $\mathrm{ha}^{-1}$ allowable to cut was determined, and this would cause minimum damage on the residual stands of commercial species. The area with low damage due to low cutting intensity was $45 \times 45 \mathrm{~m}^{2}$ or $2,025 \mathrm{~m}^{2}$, thus the number of trees ha ${ }^{-1}$ which could be sustainably felled was 5 trees ha-1. The suggested total number of trees felled in this study was smaller than that of the previous study result in East Kalimantan. Sist and Nguyen-The (2001) reported that the amount of basal area removed due to forest harvesting activities in East Kalimantan was not more than $15 \%$ of the

Table 4 Levels of damaged residual stands of commercial species due to low cutting intensity and high cutting intensity $(\mathrm{N}=29$ plots)

\begin{tabular}{|c|c|c|c|c|c|c|c|c|}
\hline \multirow{4}{*}{$\begin{array}{l}\text { Cutting } \\
\text { intensity (trees } \\
\mathrm{ha}^{-1} \text { ) }\end{array}$} & \multicolumn{8}{|c|}{ Stage of tree growth } \\
\hline & \multicolumn{4}{|c|}{ Poles } & \multicolumn{4}{|c|}{ Trees } \\
\hline & \multirow{2}{*}{$\begin{array}{l}\text { Before cutting } \\
\text { (n) }\end{array}$} & \multirow{2}{*}{$\begin{array}{c}\begin{array}{c}\text { After } \\
\text { cutting }\end{array} \\
\text { (n) }\end{array}$} & \multicolumn{2}{|c|}{$\begin{array}{l}\text { Damaged } \\
\text { trees }\end{array}$} & \multirow{2}{*}{$\begin{array}{l}\text { Before cutting } \\
\text { (n) }\end{array}$} & \multirow{2}{*}{$\begin{array}{c}\begin{array}{c}\text { After } \\
\text { cutting }\end{array} \\
(\mathrm{n})\end{array}$} & \multicolumn{2}{|c|}{$\begin{array}{c}\text { Damaged } \\
\text { trees }\end{array}$} \\
\hline & & & (n) & $(\%)$ & & & (n) & $(\%)$ \\
\hline 0.77 & 4,845 & 4,732 & 113 & 2.33 & 5,149 & 5,055 & 94 & 1.81 \\
\hline 10 & 4,845 & 3,560 & 1,285 & 26.5 & 5,149 & 4,026 & 1,123 & 21.8 \\
\hline
\end{tabular}

Table 5 The number of commercial trees with a diameter of $\geq 10 \mathrm{~cm}$ damaged due to high cutting intensity based on diameter classes and species groups $(\mathrm{N}=29$ plots $)$

\begin{tabular}{lcccccccc}
\hline \multirow{2}{*}{ Species group } & \multicolumn{4}{c}{ Diameter classes (cm) } & \multicolumn{2}{c}{ Total } \\
\cline { 2 - 8 } & $10-19$ & $20-29$ & $30-39$ & $40-49$ & $\geq 50$ & $\mathrm{n}$ & $\%$ \\
\hline Dipterocarp & 250 & 99 & 82 & 36 & 21 & 488 & 20.3 \\
Non- Dipterocarp & & 1,035 & 549 & 259 & 33 & 14 & 1,890 & 79.7 \\
All Species & $\mathrm{n}$ & 1,285 & 648 & 341 & 99 & 35 & 2,408 & - \\
& $\%$ & 53.4 & 26.9 & 14.2 & 4.1 & 1.4 & - & - \\
\hline
\end{tabular}


initial basal area. Forest harvesting activity using the RIL technique with cutting intensity of 8 trees per ha ${ }^{-1} 1$ resulted in forest damages lower than the limit.

The study results of residual stand damages using the selective cutting in Indonesia have provided facts and reinforcement on the need for the addition of restrictions on the silvicultural system of TPTI. In addition to diameter limitation of trees may be cut, other restrictions such as the number of trees to be felled $\mathrm{ha}^{-1}$ and low damages cutting distance can be made into additional restrictions in the TPTI system, so that the damage level of forests can be reduced and tropical natural forests in Indonesia can be maintained. This assertion is important and crucial, considering the fact that the total number of trees felled $\mathrm{ha}^{-1}$ on cutting practices on the forest concessionaire in Indonesia has reached an average of more than 10 trees ha $^{-1}$ (Bertault \& Sist 1993; Cannon et al. 1994). Kuswandi (2003) found that the number of trees that could be cut at other locations in Papua Province varied from 10-25 trees ha ${ }^{-1}$ with an average of 15 trees ha ${ }^{-1}$ (19 trees plot $^{-1}$.

Restrictions on the allowable number of felled trees ha ${ }^{-1}$ and low damages cutting distance will reduce the density of skidroad network, so that forest stand damages due to skidding can be minimized. The addition of low impact felling distance requires the implementation of a comprehensive forest inventory before cutting. In the forest inventory before cutting (known as ITSP) activities undertaken so far, the data were collected associated with the tree felled including tree species and diameter, but for the determination of low impact felling distance, additional data including the location and height of the tree felled are also required. With the advancement of technology and previous study results, collecting data on individual tree characteristics (height and diameter) is not a problem anymore. If the measurement of height of tree felled becomes a technical constraint in the field, the height of the tree felled can be approached using the tree height prediction model based on tree diameter (Fang \& Bailey 1998; Huang et al. 2000; Newton \& Amponsah 2007; Sharma \& Parton 2007; Adame et al. 2008).

\section{Conclusion}

This study managed to collect important information on the damages of residual stands of commercial species with a diameter of $\geq 10 \mathrm{~cm}$ due to tree cutting on a silvicultural system of TPTI. The cutting with a low intensity level results in low level damage of commercial species. However, a high cutting intensity results in high level damage of commercial and non-commercial species, and threatens the sustainability of production natural forests. Residual stand damages caused by cutting in natural forests in Indonesia can be reduced at the lowest level, if the restrictions on total number of trees that can be cut per hectare and low impact felling distance are included in the TPTI system.

\section{References}

Adame P, del Rio M, Carnellas I. 2008. A mixed nonlinear height-diameter model for Pyrenean oak (Quercus pyrenaica Wild). Forest Ecology and Management 256:88-98. http://dx.doi.org/10.1016/j.foreco.2008. 04.006 .

Behjou FK, Mollabashi OG. 2012. Selective logging damage to unharvest trees in a Hyrcanian Forest of Iran. Forest Ecology and Management 7(4):48674874.

Bertault J-G, Sist P. 1997. An experimental comparison of different harvesting intensities with reduced-impact and conventional logging in East Kalimantan, Indonesia. Forest Ecology and Management 94:209-218. http://dx.doi.org/10.1016/S03781127(96)03974-6.

Brearly FQ, Prajadinata S, Kidd PS, Proctor J, Suriantata. 2004. Structure and floristics of an old secondary rain forest in Central Kalimantan, Indoneisa, and a comparison with adjacent primary forest. Forest Ecology and Management 195:385-397. http://dx.doi.org/10.1016/j.foreco.2004.02.048.

Cannon CH, Peart DH, Leighton M, Kartawinata K. 1994. Structure of lowland rainforest after selective logging in West Kalimantan, Indonesia. Forest Ecology and Management 67:49-68. http://dx.doi.org/ 10.1016/0378-1127(94)90007-8.

Fang Z, Bailey RL. 1998. Height-diameter models for tropical forests on Hainand Island in southern China. Forest Ecology and Management 110:315-327. http://dx.doi.org/10.1016/S0378-1127(98)00297-7.

Hamilton C. 1997. The sustainability of logging in Indonesia's tropical forest. Ecological Economic 21:183-195. http://dx.doi.org/10.1016/S09218009(96)00102-4.

Han H-S, Kellog LD. 2000. A comparison of sampling method for measuring residual stand damage from commercial thinning. http://journal.hil.unbca/index.php/IJFE/article/view/9945/10159. (26 September 2012).

Huang S, Price D, Titus SJ. 2000. Development of ecoregion-based height-diameter models for white spruce in boreal forests. Forest Ecology and Management 129:125-141. http://dx.doi.org/10. 1016/S0378-1127(99)00151-6.

Indrawan A. 2003. Model sistem pengelolaan hutan alam setelah penebangan dengan sistem tebang pilih Indonesia. Jurnal Manajemen Hutan Tropika 9(2):19-33.

Iskandar H, Snook LK, Toma T, Machdiken KG, Kanninen M. 2006. A comparison of damage due to logging under different forms of resource access in East Kalimantan, Indonesia. Forest Ecology and 
Management 237:83-93. http://dx.doi.org/10.1016/j. foreco.2006.09.079.

Jackson SM, Fredericksen TS, Malcolm JR. 2002. Area distributed and residual stand damage following logging in Bollivian tropical forest. Forest Ecology and Management 166:271-283. http://dx.doi.org/ 10.1016/S0378-1127(01)00681-8.

Johns JS, Barreto P, Uhl C. 1996. Logging damage during planned and unplanned logging operation in the eastern Amazon. Forest Ecology and Management 89:59-77. http://dx.doi.org/10.1016/S03781127(96)03869-8.

Krueger W. 2004. Effect of future crop flagging and skid trail planning on conventional diameter limit logging in Bolivian tropical forest. Forest Ecology and Management 188:381-393. http://dx.doi.org/ 10.1016/j.foreco.2003.08.006.

Kuswandi R. 2003. Dampak penurunan diameter tebang terhadap kerusakan tegakan tinggal dan keterbukaan lahan pada areal HPH di Papua. Buletin Penelitian Hutan 641:35-43.

Lexerod NL, Eid T. 2006. Assesing sustainability for selective cutting using stand level index. Forest Ecology and Management 237:503-512. http://dx.doi.org/10.1016/j.foreco.2006.09.071.

Medjibe V, Putz FE, Starkey MP, Ndouna AA, Memiaghe HR. 2011. Impacts of selective logging on aboveground forest biomass in the Monts de Cristal in Gabon. Forest Ecology and Management 262:17991806. http://dx.doi.org/10.1016/j.foreco.2011. 07.014

Modig E, Magnusson B, Valinger E, Cedergen J, Lundqvist L. 2012. Damage to residual stand caused by mechanized selection harvest in uneven-aged Picea abies dominated stands. Silva Fennica 46(2):267-274.

Muhdin et al. 2008. The variability of stand structure of logged-over natural forest. Jurnal Manajemen Hutan Tropika 14(2):82-88.

Muhdin et al. 2011. Estimation of stand structure dynamics of logged-over natural forests. Jurnal Manajemen Hutan Tropika 17(1):1-9.

Newton PF, Amponsah IG. 2007. Comparative evaluation of five height-diameter models developed for black and jack pine stand-types in term of goodness-of-fit and predictive ability. Forest Ecology and Management 247:149-166. http://dx.doi.org/10. 1016/j.foreco.2007.04.029
Nikooy M, Rashidi R, Kocheki G. 2010. Residual tree injury assessment after selective cutting in broadleaf forest in Shafaroud. Caspian Journal Environtmental Science 8(2):173-179.

Osmaton FC. 1968. The Managements of Forests. London. George Allen and Unwin LTD.

Putz FE, Pinard MA, Tay J. 2000. Lessons learned from the implementation of reduced impact logging in hilly terrain in Sabah, Malaysia. International Forestry Review2 (1): 33-39.

Putz FE, Sist P, Fredericksen T, Dykstra D. 2008. Reduced impact logging: challenges and opportunities. Forest Ecology and Management 256:1427-1433. http://dx.doi.org/10.1016/j.foreco.2008.03.036.

Sharma M, Parton J. 2007. Height-diameter equations for boreal tree species in Ontario using a mixed-effects modelling approach. Forest Ecology and Management 249:187-198. http://dx.doi.org/10. 1016/j.foreco.2007.05.006.

Sist P, Nolan T, Bertault J-G. 1998. Harvesting intensity versus sustainability in Indonesia. Forest Ecology and Management 108:251-260. http://dx.doi.org/ 10.1016/S0378-1127(98)00228-X.

Sist P, Nguyen-The N. 2001. Logging damage and the subsequent dynamic of dipterocarp forest in East Kalimantan (1990-1996). Forest Ecology and Management 165:85-103. PII:S0378-1127(01) 00649-1. http://dx.doi.org/10.1016/S03781127(01)00649-1.

Sist P, Sheil D, Kartawinata K, Priyadi H. 2003. Reduced impact logging in Indonesian Borneo: some results confirming the need for new silviculture prescription. Forest Ecology and Management 179:415-427. http://dx.doi.org/10.1016/S0378-1127(02)00533-9.

Soerianegara I. 1971. Sistem-sistem silvikultur untuk hutan tropika di Indonesia. Pengumuman No: 98. Bogor. Lembaga Penelitian Hutan.

Uutera J, Tokola T, Maltamo M. 2000. Differences in the structure of primary and managed forest in East Kalimantan, Indonesia. Forest Ecology and Management 129:63-74. http://dx.doi.org/ 10.1016/S0378-1127(99)00157-7.

Verissimo A, Barreto P, Maltos M, Tarifa R, Uhl C. 1992. Logging impacts and prospect for sustainable forest management in old Amazonian frontier: The case of Paragominas. Forest Ecology and Management 55:169-199. http://dx.doi.org/10.1016/03781127(92)90099-U. 